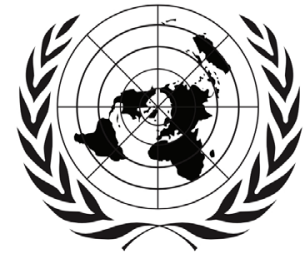

United Nations

ECLA C
ECLAC SUBREGIONAL HEADQUARTERS FOR THE CARIBBEAN

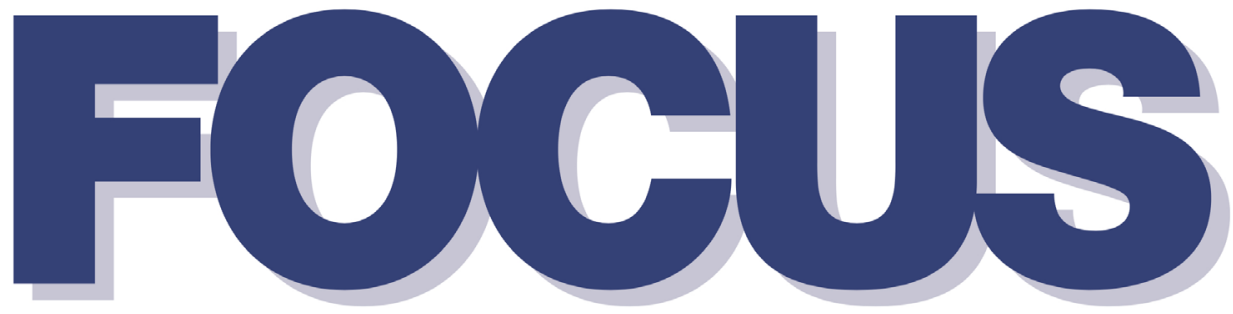

Magazine of the Caribbean Development and Cooperation Committee (CDCC)

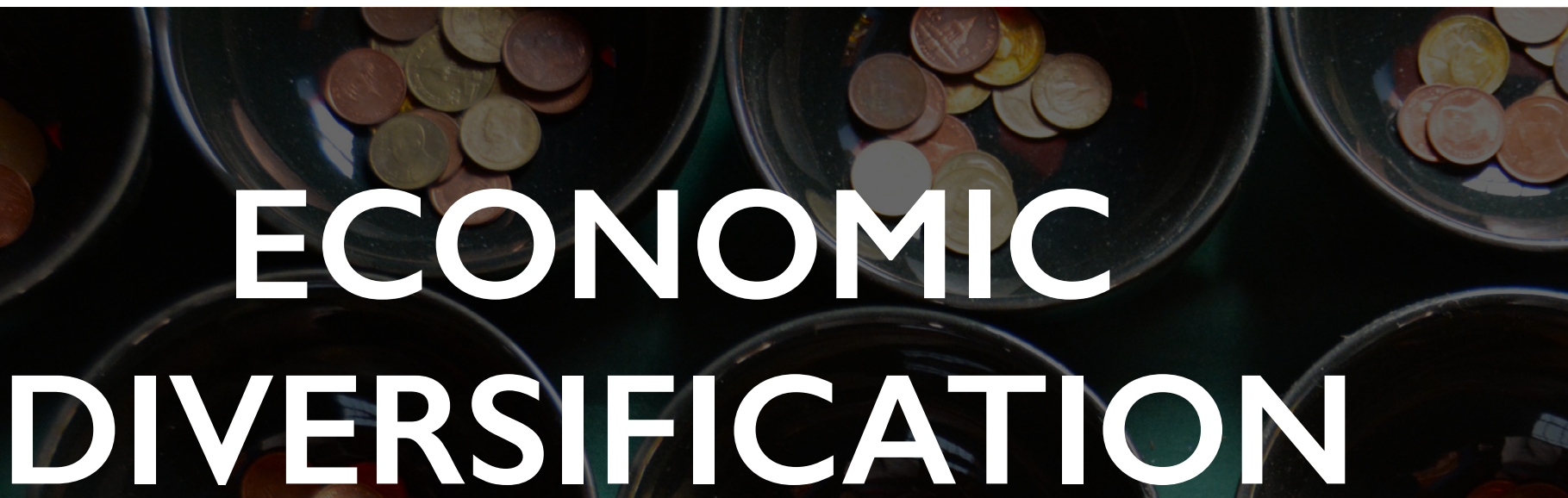




\section{ABOUT ECLAC/CDCC}

The Economic Commission for Latin America and the Caribbean (ECLAC) is one of five regional commissions of the United Nations Economic and Social Council (ECOSOC). It was established in 1948 to support Latin American governments in the economic and social development of that region. Subsequently, in 1966, the Commission (ECLA, at that time) established the subregional headquarters for the Caribbean in Port of Spain to serve all countries of the insular Caribbean, as well as Belize, Guyana and Suriname, making it the largest United Nations body in the subregion.

At its sixteenth session in 1975, the Commission agreed to create the Caribbean Development and Cooperation Committee (CDCC) as a permanent subsidiary body, which would function within the ECLA structure to promote development cooperation among Caribbean countries. Secretariat services to the CDCC would be provided by the subregional headquarters for the Caribbean. Nine years later, the Commission's widened role was officially acknowledged when the Economic Commission for Latin America (ECLA) modified its title to the Economic Commission for Latin America and the Caribbean (ECLAC).

\section{Key Areas of Activity}

The ECLAC subregional headquarters for the Caribbean (ECLAC/CDCC secretariat) functions as a subregional think-tank and facilitates increased contact and cooperation among its membership. Complementing the ECLAC/CDCC work programme framework, are the broader directives issued by the United Nations General Assembly when in session, which constitute the Organisation's mandate. At present, the overarching articulation of this mandate is the Millenium Declaration, which outlines the Millenium Development Goals.

Towards meeting these objectives, the Secretariat conducts research; provides technical advice to governments, upon request; organizes intergovernmental and expert group meetings; helps to formulate and articulate a regional perspective within global forums; and introduces global concerns at the regional and subregional levels.

Areas of specialization include trade, statistics, social development, science and technology, and sustainable development, while actual operational activities extend to economic and development planning, demography, economic surveys, assessment of the socio-economic impacts of natural disasters, climate change, data collection and analysis, training, and assistance with the management of national economies.

The ECLAC subregional headquarters for the Caribbean also functions as the Secretariat for coordinating the implementation of the Programme of Action for the Sustainable Development of Small Island Developing States. The scope of ECLAC/CDCC activities is documented in the wide range of publications produced by the subregional headquarters in Port of Spain.

\section{MEMBER COUNTRIES}

ASSOCIATE MEMBERS:

$\begin{array}{ll}\text { Antigua and Barbuda } & \text { Haiti } \\ \text { The Bahamas } & \text { Jamaica } \\ \text { Barbados } & \text { Saint Kitts and Nevis } \\ \text { Belize } & \text { Saint Lucia } \\ \text { Cuba } & \text { SaintVincent } \\ \text { Dominica } & \text { and the Grenadines } \\ \text { Dominican Republic } & \text { Suriname } \\ \text { Grenada } & \text { Trinidad and Tobago } \\ \text { Guyana } & \end{array}$

Anguilla

Aruba

British Virgin Islands

Cayman Islands

Curaçao

Guadeloupe

Martinique

Montserrat

Puerto Rico

Sint Maarten

Turks and Caicos Islands

United States Virgin

Islands
Director's Desk:

Economic Diversification

Diversification and Industrial policy:

Some conceptual considerations and a way forward for the Caribbean

Improving export performance and promoting industrialization in Caribbean:The curious case of goods producing economies

Education for Diversification

Advocating Local Content Policy as a Strategy to Revitalise Trinidad and Tobago

\section{Regular Features}

Recent and upcoming meetings

List of Recent ECLAC Documents and

Publications
FOCUS: ECLAC in the Caribbean is a publication of the Economic Commission for Latin America and the Caribbean (ECLAC) subregional headquarters for the Caribbean/Caribbean Development and Cooperation Committee (CDCC).

\section{EDITORIAL TEAM:}

\section{Director}

Editor

Copy Editor

Coordinator

Design

Cover Photo: Courtesy Pixabay.com

\section{Produced by ECLAC}

\section{CONTACT INFORMATION}

ECLAC Subregional Headquarters for the Caribbean PO Box I I 13, Port of Spain, Trinidad and Tobago Tel: (868) 224-8000

E-mail:spou-pos@eclac.org Website:www.eclac.org/portofspain 


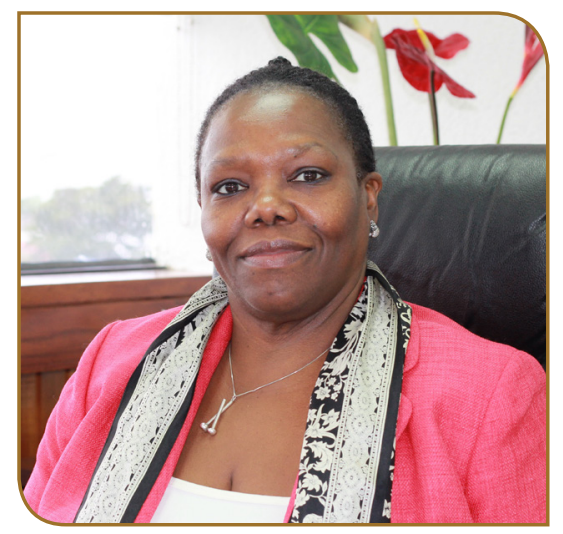

\section{DIRECTOR'S DESK: ECONOMIC DIVERSIFICATION}

This issue of the Focus explores the economic diversification of Caribbean countries as a strategy for reducing income volatility which resulted from the unexpected decline in commodity prices, and from the fall in demand for services exports arising from stagnation in some markets. The concentration of exports in tourism, or in a few primary products, has historically made Caribbean economies extremely vulnerable to external shocks.

$\mathbf{I}$ ndeed, the importance of economic diversification has gained renewed interest in the aftermath of the global economic and financial crisis of 2008-2009, particularly since the income loss incurred during the post-crisis years weighed heavily on countries. For these reasons, export diversification with a view to building the economic resilience of the countries of the subregion is critical.

This edition of Focus therefore reviews recent research undertaken by the ECLAC Caribbean team in areas that offer scope for diversifying the economic base of Caribbean countries. We begin with a conceptual piece that reflects on the critical elements that should be part of a country's industrial policy if it is to foster effective economic diversification; an optimum strategy for picking winners; fostering public-private partnership; the use of evidence-based criteria for measuring success, and the need for sunset clauses; the importance of promoting principles such as accountability and transparency.

The results of recent studies are then presented to stimulate thought and discussion on opportunities for diversification in the Caribbean. The first describes the trade performance of Belize, Suriname and Trinidad and Tobago with the European Union (EU) under the existing Economic Partnership Agreement (EPA). The study identified challenges and constraints faced by exporters in these countries, and presented possible avenues for strengthening export expansion. The study concluded that industrial policy can be designed to facilitate economic diversification. requires making choices, which means prioritising activities and facilitating the process of self-discovery. However, emphasis should be placed on activities which have spill-over effects, rather than merely impacting targeted sectors.

In order to develop a new industry, policy makers will need to take the right steps years, even decades in advance. The next article therefore identifies the diversification of production as a long term development priority, and a fundamental factor for successful development is human capital. In this regard, educating the labour force increases its efficiency and productivity, as well as its intellectual flexibility, which is key to adapting to new technologies and industries. Any government seeking to achieve diversification must therefore ensure that the education system is reformed to prepare students for participation in current and future industries targeted by industrial policies.

Furthermore, policy intervention should also be geared towards developing local capacity. The final article on local content policy (LCP) describes how this Embarking on any industrial policy can be used as a capacity development tool, insofar as it helps establish linkages between the natural resource extractive sector and the non-extractive sector. Indeed, local content policy (LCP) can increase the amount of value added captured domestically. LCP can be used to complement industrial policy to encourage the production of inputs, develop the competencies of human capital, strengthen the backward and forward linkages, and help economies build resilience to withstand unforeseen negative economic shocks.

It is important to address the Caribbean development dilemma in a holistic manner while fostering structural change and economic diversification. To do so, ECLAC proposes to focus on the development of sectors that will enhance growth and build economic resilience rather than achieve mere stabilization after each successive economic shock. This edition seeks to provoke deep thought on a way forward towards meaningfully strengthening the economic foundation of the Caribbean.

Yours in Focus

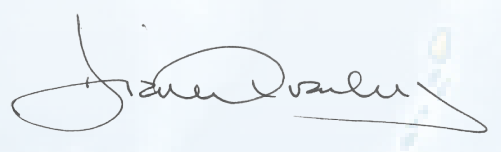

Diane Quarless 


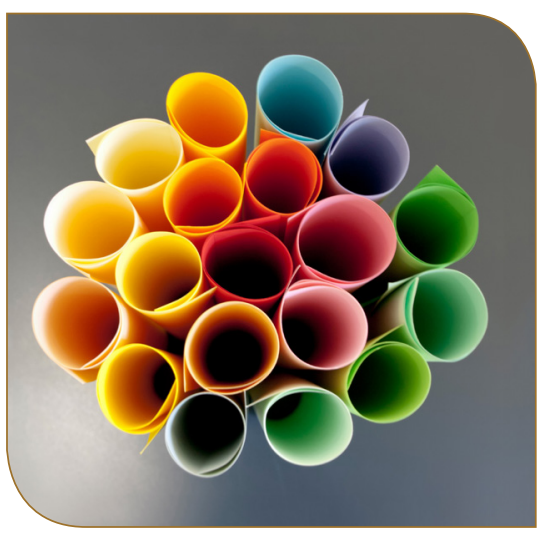

DIVERSIFICATION AND INDUSTRIAL

POLICY: SOME CONCEPTUAL

CONSIDERATIONS AND A WAY FORWARD FOR THE CARIBBEAN

Dillon Alleyne

The calls for economic diversification have been expressed more frequently by Caribbean policy makers, since the global economic crisis of 2008-2009. Three main factors account for this.
 irst, there is widespread evidence that dependence on a narrow range of products and markets magnifies income volatility, widens the current account deficit and negatively affects medium term growth. ${ }^{1}$ Second, the perspective that the market is the primary instrument of efficient resource allocation and growth has been undermined by success stories among developing counties that have used industrial policy to advance their development agenda. Third, the view that industrial policy is flawed because governments cannot pick winners has come under scrutiny as new evidence suggests that past industrialisation strategies have had some success. ${ }^{2}$

In discussing economic diversification, it is important to distinguish between horizontal and vertical diversification. On the one hand, horizontal diversification is a change in the primary export mix which implies that the number of export sectors has increased. Vertical diversification on the other hand involves contriving further uses for existing and new innovative commodities by means of value-added ventures such as processing and marketing. Diversification when mentioned in the
Caribbean context refers generally to both aspects in addition to changes in the domestic economic structure. ${ }^{3}$

\section{WHICH KIND OF INDUSTRIAL POLICY?}

It is now common to argue that changing the structure of exports requires changes in the structure of domestic production through industrial policy.

Such policies have had a chequered reputation in the past in Latin America and the Caribbean where they tended to entrench special interests and encourage inefficient patterns of production. The arguments for promoting industrial policy have been resurrected by Rodrick (2004) and others who argue that markets left by themselves will not produce the structural change necessary for development since there is a cost to self-discovery. Self-discovery refers to the ability of a firm to understand the cost structure of an activity which would allow that firm to be competitive. Further more, because the incumbent firm would not be protected from competitors, there would be no incentive to commence the self-discovery search process. The implication is that businesses need some initial protection of their ideas to encourage them to invest.

While much of this analysis focuses on how to encourage new products, the empirical trade literature suggests that countries grow more by producing greater quantities of existing goods in new and existing markets (the intensive margin), rather than by generating new exports (the extensive margin). This notwithstanding, embarking on any industrial policy requires making choices, which means prioritising activities. Rodrick (2004) is careful to argue that what must be identified are not sectors but activities which have spill-over effects. Whatever the approach, some initial identification of activities must occur if a genuine industrial policy is to be pursued. This article identifies aa set of inter-related strategies that could guide an industrial policy for the Caribbean.

\section{PUBLIC AND PRIVATE SECTOR PARTNERSHIP}

It is well recognised that bureaucracies in the Caribbean do not generally have a track record of efficiency (Anatol 2010). ${ }^{5}$

However, although it remains unclear

\footnotetext{
${ }^{1}$ Chris Papageorgiou and Nikola Spat.(2014) Economic Diversification in LICs: Stylized Facts and Macroeconomic Implications. I M F staff Discussion Note. December 14, 2012 SDN/12/13; Yvonne Tsikata, Emmanuel Pinto Moreira Pamela Coke Hamilton. Accelerating Trade and Integration in the Caribbean Policy Options for Sustained Growth, Job Creation, and Poverty Reduction. World Bank.2009; ECLAC. Structural change for equality. An Integrated Approach to

Development. Thirty-fourth session of ECLAC San Salvador,27 - 31 August.

${ }^{2}$ Henry Burton, Import Substitution in Handbook of development Economics, Vol2.Ed; Hollis Chenery and T .N Srinivasan. (Amsterdam:North Holland, 1989) pp.1601-43.
}

${ }^{3}$ This is important since Guyana has a wide range of exports but most in primary processing.

${ }^{4}$ Danny Rodrick (2004) .Industrial Policy for the 21 Century. John F. Kennedy School of Government. Kennedy Street Cambridge, MA 02138. UNIDO. 
whether there is enough capacity to take on large scale industrial restructuring, due to lack of coordination among various activities, including marketing and research and development, there are opportunities which could give bureaucracies a push start, so to speak. First there has to be greater collaboration between the private sector (more broadly defined rather than confined to a few well established interest groups) and the public sector to seek out new activities and to share costs where necessary. The role of PPP can be critical to industrial policy since governments may lack financial resources and entrepreneurial talent to develop new business activities. In addition, governments as partners to the private sector, help to reduce private risks and encourage more investment. Moreover, collaboration creates learning opportunities for the public sector. However, given that not all projects will be successful, such collaboration must be transparent, and policymakers must be ready to abandon projects and ideas in the face of evidence of failure. At the same time, public servants must also have the flexibility to recognise opportunities and to act on them quickly. Under the current arrangements, in which the incentives for innovation and change by public servants are not usually encouraged, new institutional forms may be necessary to create a more dynamic public sector.

Rodrick (2004) makes the point that institutions tasked with implementing industrial policies must be the ones with a track record of success. In this case, the implementing capacity of the public sector may be even more restricted. ${ }^{6}$ One way in which public policy can be helpful is to use targeted public procurement policies to assist historically excluded groups such as women and youth to improve their participation in government funded projects and programmes.

\section{THE CHALLENGE OF PICKING WINNERS}

The idea of picking winners by policy makers, is very contentious in the economic literature because it is recognised that the private sector will bear the cost of unwise investment while bureaucrats may only face reputational risks.

In addition, there is no reason to believe that the public sector has any more information than other groups with respect to what sectors or activities will be successful. For this reason, the preference is to focus on activities rather than on sectors. For example, governments can invest in improving marketing and information flows and implement quality standards, which raise the performance of a broad range of firms. They can also build facilities to encourage clusters of activities which encourage learning through agglomeration and attract the relocation of specialised skills.

It is also argued that the composition of a country's basket of goods matters as well as its areas of specialisation. In other words, producing potato chips is not similar to producing computer chips as the latter requires higher order skills. Depending on the type of diversification being pursued, industrial policy should focus on export competitiveness, product quality, and on activities having a certain amount of local content (human or material) or innovative capacity. For example, in economies which are foreign exchange constrained, the emphasis should be on import substituting activities and firms that are able to use local inputs efficiency for exports. In general, all or some of these ideas could guide the list of activities to be supported by public policy.

\section{SUNSET CLAUSES AND EVIDENCE BASED SUCCESS CRITERIA}

It should be a principle of industrial policy design that all projects that have some support from the government should have a sunset clause that sets out the termination of that support (Rodrick 2004 ).

This creates an incentive for firms to improve their competitiveness in light of the certain removal of support. Critical to such an arrangement would be proper record keeping, which would be needed to stymie those operators who would seek to remain in the programme when they should depart. Any successful attempt to game the system will create distortions between those who are genuine performers and those who are not. For this reason, decision making must rely on evidence based procedures rather than on discretion.

- (continued on page / I)

\footnotetext{
${ }^{6}$ The SDG agenda recognises both the need for industrial policy and diversification. Subgoal 8.2 of the SDG agenda, calls for the achievement of higher levels of economic productivity through diversification, technological upgrading and innovation, including through a focus on high-value added and labour-intensive sectors. In addition goal 9 calls for building inclusive and sustainable industrialisation.
} 


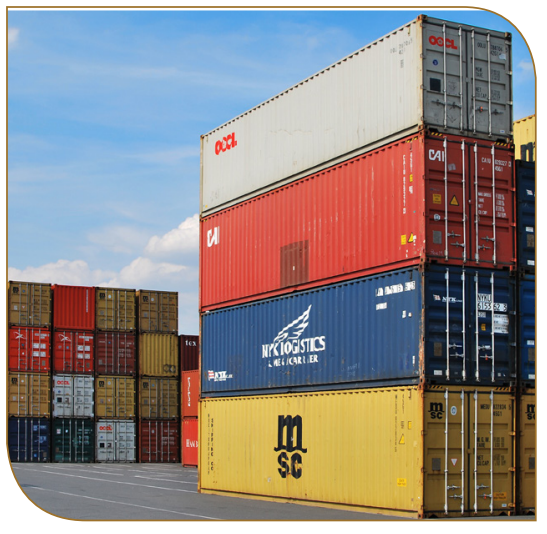

IMPROVING EXPORT PERFORMANCE AND PROMOTING INDUSTRIALIZATION IN THE CARIBBEAN: THE CURIOUS CASE OF GOODS PRODUCING ECONOMIES

Sheldon Mc Lean

The World Trade Organization (WTO) Agreement (1995), and its predecessor, the General Agreement on Tariffs and Trade (GATT), ushered in an era of international commerce which has been characterized by the gradual removal and lowering of barriers to trade, as well as trade distorting measures such as quantitative restrictions, subsidies and tariffs.

$\mathbf{W}$ ith the gradual dismantling of trade restrictions, the WTO's policy regime established the basis for freer trade and improved market access for exports. At the same time the numbers of regional trade (preferential) agreements (RTAs) $^{1}$ has steadily increased since the establishment of the WTO, as groups of economies attempt to secure favorable improved market access conditions among themselves. This is regarded as necessary to generate additional demand to boost exports as well as to exploit opportunities for joint production.

In relatively small, open economies such as those in the Caribbean, the export sector plays a strategic role in fostering the diversification of a country's economic base and improving growth rates on a sustainable basis. This is possible due to a liberalized global trading environment, which offers significant opportunities for expansion

of economic activity via increasing exports. However, capitalizing on such opportunities calls for the development of focused policies and strategies, including those related to investments, as well as the provision of support services to enterprises in meeting the many challenges associated with international trade. Indeed, despite having relatively open economies and espousing a focus on export expansion, free trade has not truly become the integral vehicle of growth and development for Caribbean economies as originally envisaged.

ECLAC Caribbean recently completed a study which focused on the identification of the challenges and capacity constraints faced by enterprises in the sub-region in exploiting trade opportunities provided by Free Trade Agreements (FTAs), and Partial Scope Agreements (PSAs). The research also sought to develop a strategic framework

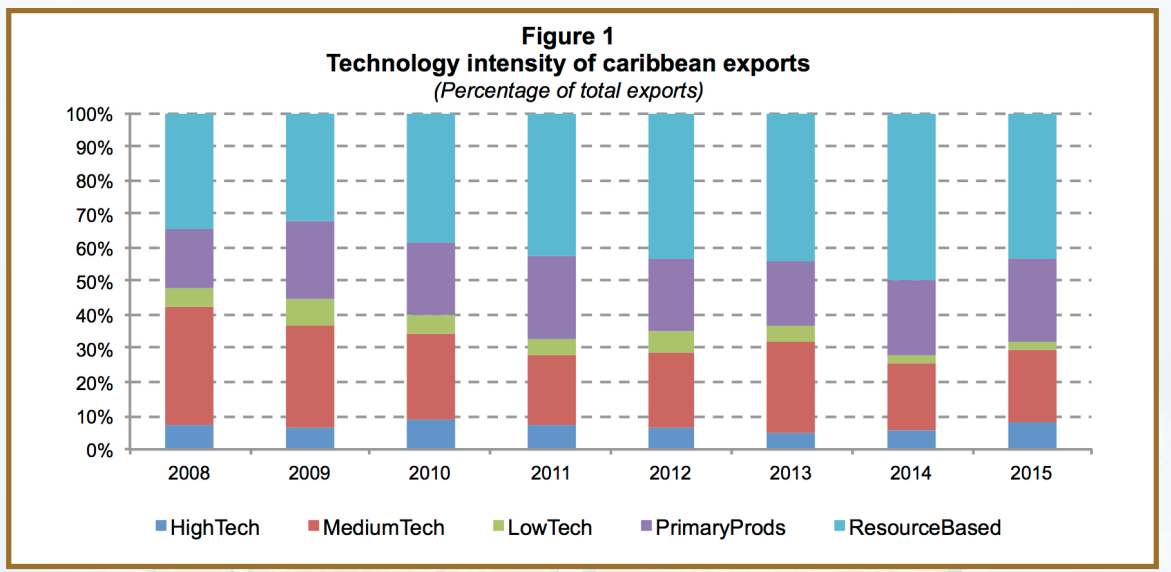

Note: Antigua and Barbuda, the Bahamas, Barbados, and Dominica have no data available. Source: COMTRADE via WITS. aimed at addressing these challenges and constraints, thereby creating a platform for export expansion and diversification.

The study was limited to the goods sector, using Belize, Suriname, and Trinidad and Tobago in a case study. For each country, two trade Agreements were selected as the basis for trade performance analysis - a Free Trade Agreement (FTA), and a Partial Scope Agreement (PSA). This article explores their recent trade performance under the selected trade agreements; identifies challenges and constraints faced by their respective exporters, and presents possible avenues for strengthening export expansion of new and existing products.

This type of analysis is useful in identifying missing elements of a strategy for expanding the region's exports. So, for example, examination of the technological sophistication of Caribbean exports reveals that the sub-region's exports have been mainly primary products and goods with relatively low levels of technological intensity in production. See Figure 1.

On average, about 98 per cent of the exports of both Guyana and Suriname fall in either the category of primary products or in that of a relatively low level of technological intensity in production. With respect to Belize and Trinidad and Tobago, these two categories make up 73 per cent and 66

${ }^{1}$ A regional trade arrangement (RTA) is a free-trade agreement, customs union or common market consisting of two or more countries 


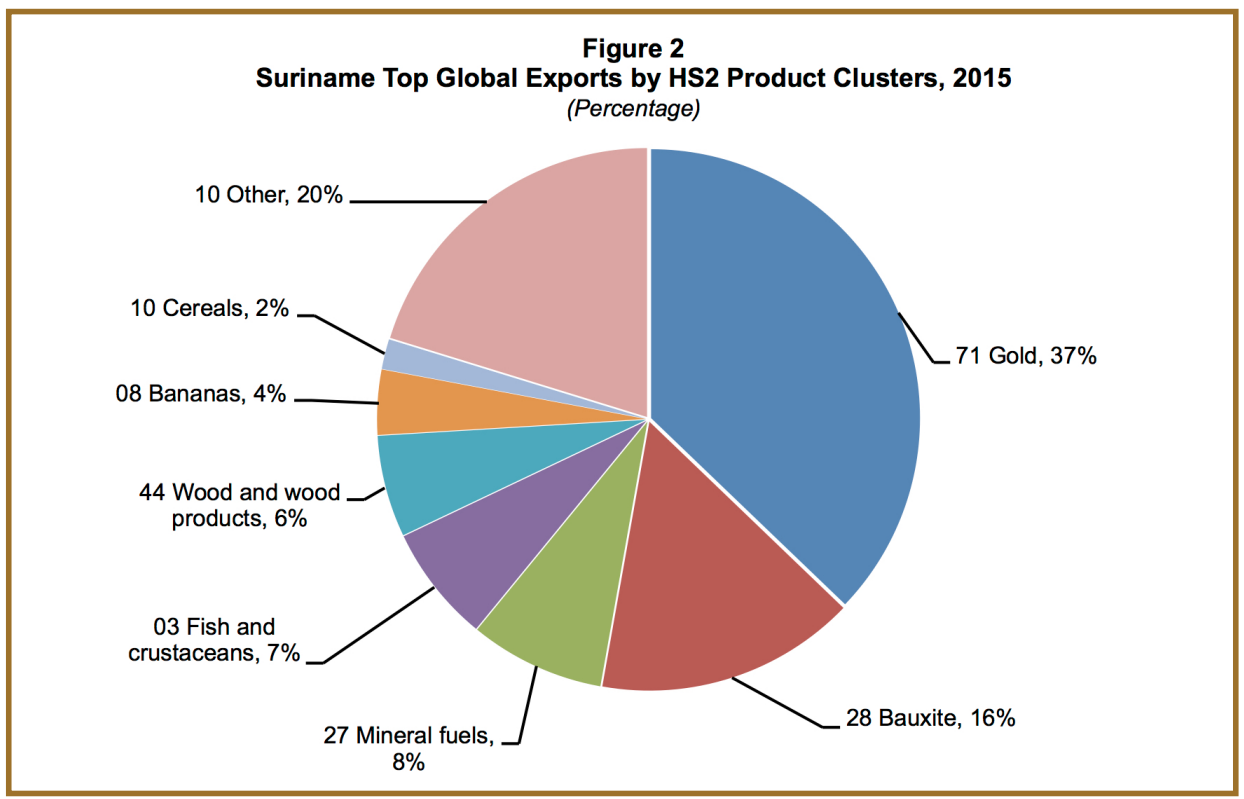

Note: Antigua and Barbuda, the Bahamas, Barbados, and Dominica have no data available. Source: COMTRADE via WITS.

per cent of all exports, respectively, on average. This highlights the need for the economies of the subregion to move further up the value chain and into the production of more manufactured goods as well as to enhance the valueadded in existing goods. ECLAC Caribbean has therefore increasingly focused on the economic transformation of Caribbean economies, with a view to guiding the region along a sustainable path towards comparative advantagebased industrialization and production integration.

\section{OVERVIEW OFTHE CASE STUDY FINDINGS}

The research revealed that where trade with the European Union (EU) under the Economic Partnership Agreement (EPA) was concerned, the Agreement had not triggered any significant change for any of the countries studied.

The basket of exports remained virtually unchanged. It was also revealed that the global recession of 2008 generally had a more pronounced effect on trade performance than the coming into force of the Agreement. Specifically, there was significant fall off in export earnings post-recession when compared to the period prior to 2008 . In the case of Trinidad and Tobago, with respect to its PSA with Colombia, significant growth in exports was discerned in the period leading to the global recession in 2008, but with sharp declines thereafter, reflecting the depressed prices of energy related products. Opportunities to increase Surinamese exports to the Cuban market and Belizean exports to the USA market with respect to fresh fruits and vegetables were also explored.

Based on consultations with exportersand trade related institutions, key challenges and constraints to export expansion were linked primarily to the need to enhance the export enabling environment, particularly with respect to trade facilitation services and trade capacity development for individual exporters and export enterprises. If we take a closer look at the export performance of the individual countries a number of observations can be made.

\section{THE CASE OF BELIZE}

In the case of Belize, in 2015, the top five exports accounted for three quarters of the total exported value ( 74.2 per cent) with each product earning over US \$20 million.

Moreover, in 2015, banana replaced crude oil as the top export at US $\$ 73$ million, followed closely by sugar at US $\$ 70$ million. The combined exported value of these two products was US $\$ 143$ million or 43 per cent of the total for the year. The other top four exports were citrus juices, preparations of vegetables and fruits, fish and crustaceans, and mineral fuels (see figure 2).

With regard to the impact of the CARIFORUM-EU EPA, with the exception of orange juice, all of Belize's top exports enjoyed duty free access to the EU market under ACP preferences prior to the coming into force of the EPA. Accordingly, the ECLAC study found that market access would not have been a factor in explaining the observed increases in export levels of some of the top exports. However, the data suggest that some of the country's exports of orange juice to the US were diverted to the EU market on the coming into force of the EPA to take advantage of the improved market access - going from 5.7 per cent ad valorem equivalent tariff prior to the EPA in 2008 to duty free entry post EPA.

The analyses also highlighted that for Belize, consideration of export to the US market should be given for agricultural products such as hot pepper, cucumber, cabbage, fresh and chilled vegetables, beans, peas, yams, chick peas, pigeon peas, sweet potatoes, papaya, coconuts, lemons, mandarin, watermelon, avocado and frozen fruits. In addition, orange as well as grapefruit juice should be considered for increased exports to the EU given the increasing competiveness in this market. 


\section{IMPROVING EXPORT PERFORMANCE AND PROMOTING INDUSTRIALIZATION IN CARIBBE- AN: THE CURIOUS CASE OF GOODS PRODUCING ECONOMIES}

However, increasing exports at the intensive margin, that is expanding existing exports, may not necessarily address the vulnerability of the economy's export earnings to volatility. There is high concentration of the export basket among five products with the top two markets, bananas and sugar, accounting for approximately two thirds of the total exported value. This exposure is compounded by the fact that most of these are commodities and as such are subject to commodity price cycles.

\section{THE CASE OF SURINAME}

Suriname has a relatively diversified export market with eleven trading partners accounting for 94 per cent of the country's exports in 2015.

The top market destinations in 2015 were: Switzerland (25.6 per cent), India (17.6 per cent), Belgium (11.3 per cent), the US (11.2 per cent) and France (9.6 per cent). Suriname's global exports are however concentrated, in the top six product clusters accounting for 78 per cent of the total. In 2015, gold was the most exported item accounting for 37 per cent of total value of exports at US $\$ 1,400$ million. The other products were inorganic chemicals at 16 per cent of total exports, mineral fuels (8 per cent), fish (7 per cent), wood (6 per cent), and bananas (4 per cent) (see figure 2). ECLAC is currently building on these results, by assessing the performance at the extensive (i.e. growth in exports of new products) and intensive margin.

Switzerland is Suriname's main market destination for gold; India and China are the main markets for wood exports. Canada and the USA are the main markets for Suriname's bauxite exports. France is the main market for Suriname's mineral oils and bananas exports, whilst Jamaica was the main market for rice exports.
Specifically, Suriname's bauxite exports declined by 17 per cent versus a decline of 5 per cent for world imports, while cereal exports declined by 5 per cent compared to the decline of 2 per cent for world imports. In the case of bananas, Suriname's export increased by 1 per cent compared to an increase of 5 per cent for world imports, while exports of beverages remained unchanged as compared with a growth of 1 per cent for world imports.

Moreover, Suriname's gold, fish and wood exports have outperformed global imports, suggesting that there exists considerable potential for expanding exports of these commodities, all of which are primary products.

With regards to Suriname's trade with the EU under the EPA, the ECLAC study concluded that, to date, there appears to be no discernible effect of the EPA on exports, either in terms of growth in exported value or in the composition of the export basket. With respect to the performance of mineral exports both lower production levels and softening of prices appear to have contributed to declining export earnings. However, in the case of agricultural related industries, the rice sector experienced a significant reduction in international prices in recent years. In the case of rice and vegetables, food safety issues as well as supply issues appear to be impacting on export performance. The issue of quality, if not attended to, could limit options for increasing export revenue from these products in the future.

\section{THE CASE OFTRINIDAD AND TOBAGO}

Trinidad and Tobago's export performance with respect to both the PSA with Colombia and the EPA with the EU, indicates strong similarities in terms of the product composition of the export basket as well as trade performance over the years of analysis, $2004-2015$.

In both cases, the products comprising the top ten exports, in value terms, were dominated by hydrocarbon based products. As a consequence, export performance was largely driven by a single factor, i.e., the movement in energy prices. Accordingly, in both cases export showed rapid growth over the period $2004-2008$ and a subsequent sharp decline over the 2008 - 2015 period.

Trinidad and Tobago's export performance trends over the period 2004-2015 underscore the vulnerability to commodity price swings when the basket of top exports is narrowly concentrated. This is exacerbated by the fact that the majority of its exports is comprised of energy-based products whose performance is essentially driven by one factor, i.e., energy prices. While there doesn't appear to be an EPAeffect on the country's exports to the EU, the data seem to suggest that Trinidad and Tobago's exports to the EU are primarily driven by fluctuations in industrial demand within the EU, particularly since the majority of the country's exports to the EU are products used as intermediate inputs.

As such, it would seem that Trinidad and Tobago is in need of an export diversification strategy that is rooted in a broader industrial policy, which seeks to guide the country towards increased production of downstream high-value manufacturing. This approach should also prioritize other energy intensive industries and services, rather than focus on intermediate products, since the former are generally subject to lower levels of market volatility. Furthermore, 
these sectors would earn more value added than intermediate products.

\section{ELEMENTS OFA NEWTRADEAND DEVELOPMENT STRATEGY}

The recent export performance of all three countries examined in the ECLAC study makes a compelling case for export diversification of both products and markets, to address instability in export earnings.

Further, perusal of Figure 3 reveals that between the period 2006-2015 only Trinidad and Tobago, and to a lesser extent Belize, managed to generate positive trade balances with other CARICOM member states. Additionally, when compared to other regional integration movements such

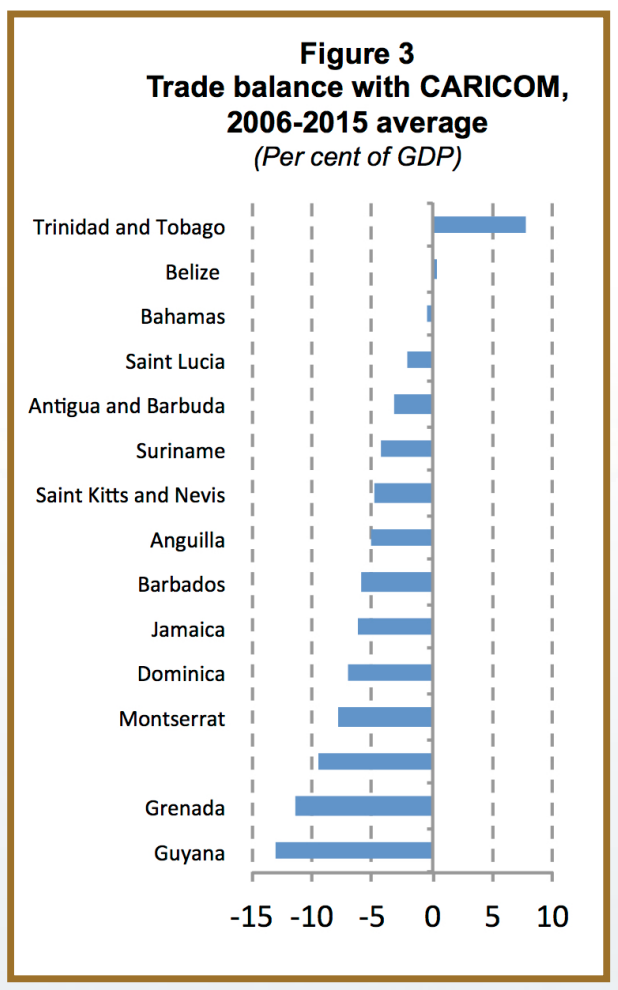

as MERCOSUR, ASEN, SICA and the EU, the Caribbean has relatively lower levels of intra-regional trade as a share of total trade, while only the EU achieved lower growth rates (20062015), see Figure 5.
Reversing the trend of low growth, vulnerability to commodity price swings, declining export performance and marginal intra-regional trade may require a fundamental shift to an approach to economic development and regional integration, which is predicated upon broader comparative advantagebased production specialization. The intuition here is that the exploitation of trade opportunities created by the subregion's entry into the various bilateral and plurilateral free trade agreements, either as a regional body or as individual member states, is not automatic as there are many pre-conditions for successful export expansion and participation in these markets, some of which are touched on below.

Structural bottlenecks may cause greater challenges to trade intraregionally rather than extra-regionally. Indeed, high transportation and logistics costs have also limited extraregional trade, and have emerged as a substantive barrier to increasing exports. This has also limited the ability of the private sector to capitalize on existing opportunities for intraindustry intra-regional trade. Hence, improving regional connectivity in the areas of transportation infrastructure

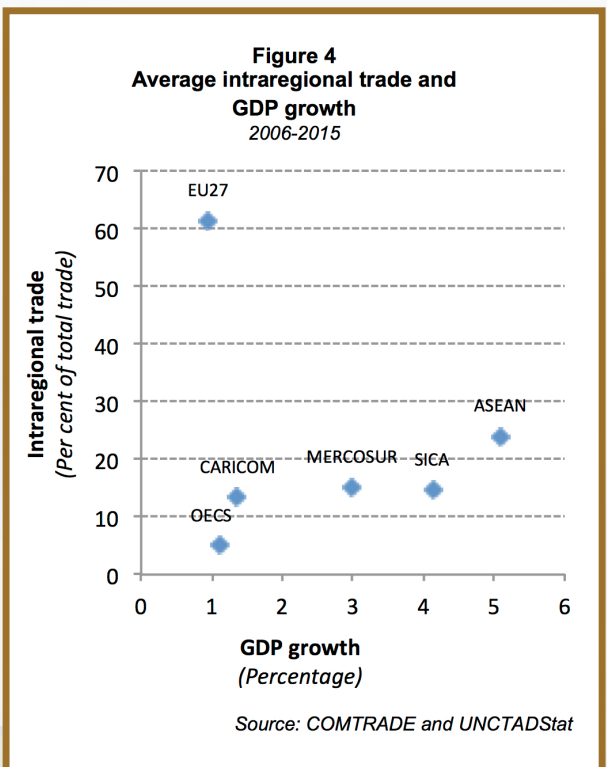

(road, maritime and air), as well as freight logistics ${ }^{2}$ and ICT should be viewed as essential to building a new platform for economic restructuring and diversification.

From a policy-setting perspective, it should be noted that expansion in global production and trade has increasingly been fueled by global value chains (GVCs), thereby fragmenting the production process and offering up opportunities for participation in segments. This has made innovation, as well as information, communication and technology important drivers of trade performance. Hence, the subregion should see the production of economic infrastructure-related public goods as a necessary lever for removing supply-side constraints in many territories. Governments must encourage the regionalization of production, which would ensure that the Caribbean generates the critical mass of specialized production activities that would allow value chain (VC) participation.

If the region is to make the best of opportunities to participate in global and regional value chains which have fueled growth in global trade since the 1990s, it is crucial that policy makers see the accumulation of physical (technology) and human capital, which facilitates more efficient use of available resources, as necessary ingredients for economic diversification. In this way, investing in a sub-regional framework for promoting innovation, intellectual property protection, research and development (R\&D) as well as technology transfer and absorption would provide a crucial lever for increasing region-wide total factor productivity and diversification of the goods and services produced in individual member states.

${ }^{2}$ With regard to transport and logistics, improvements in port facilities could significantly improve efficiency and throughput thus reducing shipping costs. Additionally, with specific reference to Belize it was suggested that greater utilization could be made of other ports in Belize such as Commerce Bight Port. 


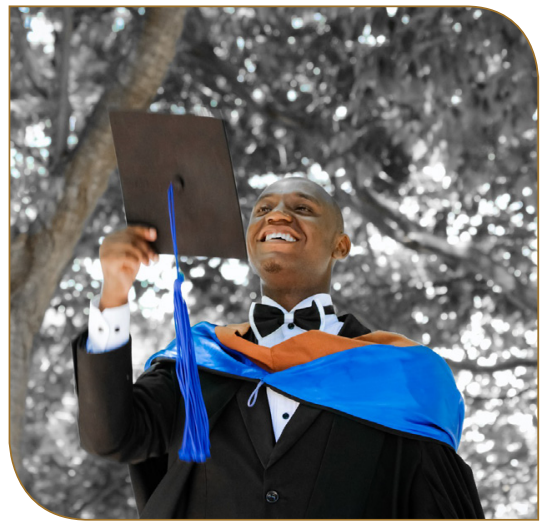

D iversification is frequently discussed following negative economic shocks, such as the decline in oil prices in 2014. However, diversification is a long-term process that cannot occur in response to any one-off shock. In order to develop a new industry, policy makers must make the right steps years and even decades in advance. This is even more difficult in our dynamic global economy. Successfully diversifying for small countries could be like hitting a moving target with a bow and arrow.

The diversification of production should be a long term development priority, and a fundamental ingredient for its success is human capital development. A skilled labour force, through education increases their efficiency and productivity, as well as their intellectual flexibility, which is key to adapting to new technologies and industries. Numerous academic studies since the 1960's have found evidence of the contribution of education to economic growth (Ozturk 2001). The Governments of the Caribbean have made much progress in improving the education levels of their citizens. In 2015, the primary completion rate was 96.4 per cent in the Caribbean, compared to 94 per cent in the rest of small economies (ROSE). The Caribbean boasts a regional examination and certification body in the Caribbean Examinations Council (CXC). The subregion also shares a premier tertiary institution, the University of the West Indies (UWI), with campuses spread around the Caribbean. However, in some of the islands, as in the rest of Latin America, there is a mismatch of skills and labour demands, which contributes to unemployment. The case of Grenada exemplifies this below.

\section{EDUCATION FOR DIVERSIFICATION}

Machel Pantin

The drive for diversification is essentially a drive for managing risk. Diversification does not always increase economic growth, but rather reduces growth variability and, as a result, consumption variability. Diversification should therefore be seen as an initiative to reduce vulnerability, which is crucial given the inherent vulnerability of Small Island Developing States. These economies, which are mostly undiversified, traditionally have most of their production focused in one or two sectors in which they would most likely have a comparative advantage.

THE CASE OF GRENADA

To pursue diversification, governments can either focus simply on providing an enabling environment and letting industries develop, or they can "pick winners", select the industries they would wish to see develop and craft policy to support them.

The government of Grenada pursued the latter approach, selecting five nontourism service sectors for further export development: Yachting and Marine, Health and Wellness, Agroprocessing, professional services, and creative industries. Grenada's economy, like those of most Caribbean islands, is dependent on tourism. According to the World Travel and Tourism Council, in 2016 travel and tourism contributed 20.2 per cent to the Gross Domestic Product (GDP) and 18.5 per cent to total employment, both directly and indirectly. While travel and tourism's absolute size in Grenada was ranked 173 out of 185 countries, its contribution to GDP was ranked 36, indicating a tourism dependent economy. Grenada also has an important agriculture sector, which produces cocoa, nutmeg and a number of other spices. Grenada's economic vulnerability was revealed in the aftermath of the global financial crisis of 2007-2008, as the economy grow by no more than 1 per cent until 2013. During this period public debt increased from 82 per cent of GDP in 2008 to 103 per cent in 2013, although the government has managed to lower its debt level after restructuring. In 2015 Grenada's unemployment was estimated at 28.9 per cent, the highest in the Caribbean, with youth unemployment even higher.
In 2015, ECLAC Caribbean, at Grenada's request, provided technical assistance for the development of five chosen sectors. ECLAC produced a study and a policy strategy for the export development of these sectors. During discussions with stakeholders, education emerged as a key factor for developing the identified sectors. The stakeholders noted that the current education system in Grenada reflected its colonial origins; that the curriculum had not evolved to cater for new services and emerging economic opportunities. The country's main technical/vocational school, which is publicly funded, teaches skills that are not matched to the labour market's needs. The need for more appropriate education stood out in two sectors in particular: yachting and marine, and the creative industries.

Grenada has eight boatyards or marinas, which attracts yachtsmen from around the region. With the development of the yachting and marine sector has come growth in ancillary services. According to a study conducted for the Marine and Yachting Association of Grenada in 2013, the sector has produced 912 jobs, both directly and indirectly. However, ECLAC found that in the yachting and marina sector the demand for trained skilled workers greatly outweighed their supply. There was need for workers in provisioning of yachts, docking of crafts, yacht chartering, and sail and boat repair among other areas. The introduction of technical and vocational training in these areas can provide the skills necessary for more Grenadians to enter this sector. This would reduce unemployment and provide the labour necessary to further develop the yachting and marine sector. Grenada has a great deal of creative and cultural talent, but has been challenged 
in developing its creative industries. ECLAC found that there was a lack of organization among artistes and performers. It was recommended that Grenada include creative and performing arts in the school curriculum at the primary and secondary level to increase the skilled labour supply for the creative industries. In addition, business classes focused on creative industries could be offered to performers. Increased education on the business of creative output would increase awareness of the need for organization among performers. Organizations of performers could set standards on artistes' remuneration and property rights, and strengthen the industry as a whole. Amateur performers would enter the official market and begin contributing to the governments tax revenue These organizations could also assist artistes will the regulatory burdens of selling their services in foreign markets, thus contributing to the country's external position as well.

ECLAC recommended that the government of Grenada adjust the curriculum of the main technical vocational school to produce graduates in these emerging sectors. Partnering with the private sector was also a main policy suggestion. A partnership between the public technical school and private industry can enhance the education sectors understanding of the job market's needs. The government can also grant concessions to private entities which offer suitable, certifiable training in areas which complement the offerings of public technical vocational schools.

\section{CONCLUSION}

There is need for more effective collaboration between government, academia and industry if we are to achieve a better match between available skills and labour demand.

To achieve improved diversification, countries will need to ensure that the education systems are reformed to prepare students for the relevant current and the future industries. Labour market information systems must be used to generate student interest in these industries. The personal return on education must be substantial enough to encourage young people to get additional schooling in the selected sectors. If prospective students are not aware of these opportunities, then they may not enter the programmes. If the returns are indeed not sufficient, then those who complete their education may choose to migrate for better employment opportunities. In countries with great excess capacity, such as Grenada, the new sectors should draw more workers from the unemployment pool rather than from other sectors to ensure that production is increased. Monitoring and evaluation should be done continuously to ensure that the education programmes are meeting the job markets needs and adapting to new changes. If these steps are taken, then Grenada (and the wider Caribbean) will have a greater chance of hitting its targets of development. -

\section{SOURCES:}

Berezin, Peter, Ali Salehizadeh and Elcior Santana. 2002. The Challenge of Diversification in the Caribbean. IMF Working Paper.

Jordan, Ava. 2016. Policy Strategy for the Export Development of Grenada's Nontourism Services Sector. (Unpublished).

Now Grenada. 2013. Yachting Sector Contributes EC\$130 M to the Economy. http://www.nowgrenada. com/2013/07/yachting-sectorcontributes-ec130m-to-the-economy/

Ozturk, Ilhan. 2001. The Role of Education in Economic Development: A Theoretical Perspective. Journal of Rural Development and Administration, Volume XXXIII, No. 1, Winter 2001, pp 39-47.

\section{DIVERSIFICATION AND INDUSTRIAL POLICY: SOME CONCEPTUAL CONSIDERATIONS AND A WAY FORWARD FOR THE CARIBBEAN}

\section{ACCOUNTABILITY AND \\ TRANSPARENCY}

If an industrial policy is to be properly implemented and its success effectively, this is best achieved within a regime of real and perceived accountability and transparency.

This is critical especially since these processes are likely to be driven by policy makers with considerable influence, such as Prime Ministers or Finance Ministers. The oversight process must be managed by an independent body which has the capacity to assess evidence and the authority to make decisions based on such evidence. Given the need for sunset clauses to terminate government commitments, at prearranged points in time, appropriate monitoring and evaluation must be addressed. Bipartisan support for such processes is important if that industrial policy is to survive successive the political business cycles.

\section{CONCLUSION}

The development of new activities and sectors will not occur by mere appeal to macroeconomic stability.
This will require carefully crafted policies aimed at the raising the share of new and existing activities in total value added. Not all aspects of such policies can be successful and allowance must be made to change course and abandon those activates that are clearly unsustainable. Where public institutions tend to be weak, fragmented and inefficient, industrial strategies are best pursued incrementally as the bureaucracy improves its capacity. There are no fool-proof approaches but proper monitoring and evaluation with the architecture of accountability is likely to bear rich results for the Caribbean. 


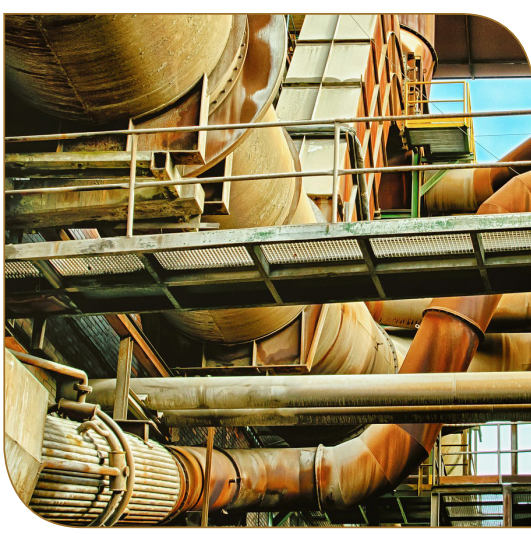

$\mathbf{T}$ he World Bank Commodities Price Forecast report predicts an oil price of US $\$ 60 /$ bbl in 2018, US\$61.5/ bbl in 2019 and US\$62.9/ bbl in 2020. For the North America regional market, natural gas forecasts are US\$3.5 / MMBtu in 2018, US\$3.6/ MMBtu in 2019, and US\$3.7/ MMBtu in 2020. Although the aforementioned forecasted prices are higher than spot prices, they are still low by oil and gas price standards.

Following the 2014 oil price crash, the Government of the Republic of Trinidad and Tobago (GORTT) has increasingly relied upon the use of public debt financing, deferred bill payments, and the selling of stocks from its few profitable enterprises, to raise funds to assist in meeting its fiscal expenses. Apart from the aforementioned strategies, there is still a viable tool which can be used to revitalize the T\&T economy. This is local content policy (LCP).

According to a World Bank publication, local content is defined as

"The extent to which the output of the extractive industry sector generates further benefits to the economy beyond the direct contribution of its value-added, as through links to other sectors." (Tordo et al. 2013, 13).

Local content can refer to jobs or valueadded that is created anywhere in the domestic economy as a result of the monetization of natural resources in an economy. It may even refer to the provision of infrastructure (schools, medical facilities) by the natural resource

ADVOCATING LOCAL CONTENT POLICY AS A STRATEGY TO REVITALISE TRINIDAD AND TOBAGO

\author{
Don Charles
}

Trinidad andTobago's (T\&T's) economy has been historically dependent on the energy sector.This dependence has resulted in the energy related boom-bust economic cycles for T\&T. It is well known that in the aftermath of the oil price crash that occurred in mid-20I4, the downward trajectory of T\&T's energy (crude oil and natural gas) production caused the economy ofT\&T to slide into a recession.

monetization company which may benefit the local population (Tordo et al. 2013).

Local content policies refer to the government policy interventions by the government geared to strengthen the backward and forward linkages of the natural resource extraction sector, which may result in the increase in the value added captured domestically.

Many countries have considered local content policy and used them with success. Among the success stories are Botswana, Chile, and Norway.

In the case of $T \& T$, the country currently has a number of legislations designed to improve local content in the country. These include:

-The Fiscal Incentives Act, Chapter 85:04, which grants fiscal incentives to qualified companies;

-The Foreign Investment Act, Chapter 70:07, which is used to attract foreign investment in areas deemed to be important to T\&T;

-The Unemployment Levy Act Chapter 75:03, which provides a fund which is used to finance employment programs in Trinidad; and

-The Petroleum Production Levy and Subsidy Act Chapter 62:02, which provides a fund which is used to finance subsidies on petroleum products.

In 2004, the GORT'T developed a LCPlabeled the "Local Content and Participation Policy and Framework". In 2006, the GORTT attempted to enhance the local content in the energy industry via the imposition of LCRs in the production sharing contracts (PSCs). The PSCs outlined mandatory requirements for procurements and local capacity development. Some of the procurement provisions included:

-Operators must maximize their utilization of goods and services produced in T\&T;

-Operators must submit work programs to the Ministry of Energy and Energy Affairs (MEEA) and clearly outline the level of local content they intend to achieve;

-Contracts shall be unbundled to match the capabilities of domestic subcontractors;

- Contracts shall be advertised locally to ensure domestic suppliers get a chance to participate in tendering; and

-Tender evaluation should place a higher weight on local content than foreign competition.

In the aspect of capacity development, the provisions included:

-Preference should be given to nationals in employment;

-Provision of training for nationals so that they may eventually replace expatriates;

-The training of nationals shall be consistent with the standards of the operator; and

-The transfer of technology to nationals in the areas of fabrication, information technology, maritime services, marketing, operational management, and business support services. 
Perhaps the biggest success story for $T \& T$ in local content in the energy sector has been in the area of offshore platform fabrication. Historically, offshore platforms were engineered and fabricated in the United States (US). The local content in such projects was low, and utilized approximately only 9 per cent of local inputs. In 2005, British Petroleum Trinidad and Tobago (bpTT) encouraged local content in the offshore platform fabrication industry via the construction of the Cannonball platform. The project was undertaken by Trinidad Offshore Fabricators Ltd (TOFCO), which is a joint venture between local company Weldfab Ltd. and Chet Morrison Ltd. (Triniview 2004).

An estimated 40 per cent of local input was used in the construction of the Cannonball platform (bpTT 2016). This 40 per cent included services such as marine transportation, the employment of nationals of $T \& T$, the purchase of goods sold by hardwares, rental of equipment from domestic contractors and subcontracting of support services such as janitorial and security. The Cannonball platform, the second drilling platform ever constructed in $T \& T$, is the first one ever built completely from local input. Since then, four additional platforms have been constructed for bpTT, these being Mango, Cashima, Savonette and Serrette. The aforementioned projects were locally designed and utilized approximately 80 per cent local labour (bPPTT 2015).

The multinational energy companies operating in T\&T, such as Atlantic LNG, bpTT, Repsol, etc., have internal policies to hire nationals of $\mathrm{T} \& \mathrm{~T}$, and purchase inputs from domestic suppliers. Some companies go a bit further in their own local content strategy. For example, while British Gas operated in the country, it partnered with the Energy Chamber to develop the Safe to Work (STOW) initiative .This program can be viewed as local content in the form of capacity development.
While the present effort to increase local content in production has been a good achievement for the country, there is room for improvement.

There is a need to further increase the amount of local inputs in production in T\&T. If more goods were produced domestically, then there would be greater output for sale to the multinationals operating in the energy sector.

The GORTT may wish to consider developing a strategy to enhance the production of local inputs in specific areas. For example, the development of platform fabrication capacity in T\&T was the result of a specific intervention. Given that T\&T intends to undertake a number of deepwater exploration and production projects within the next 5 years, support services for deepwater exploration and production companies can be a target area for development of local input supplying capacity. Some areas where local inputs/ services may be increased include: marine transportation; maritime engineering; ship repair; ship construction; bunkering; electrical installation; civil engineering and construction; mechanical engineering and machine maintenance; onshore surveying; laboratory testing; and map drawing.

There is need to improve access to financing. Many contractors may not have the financial capability to engage in some projects. Subsequently, the government can work with a financial institution and develop a fund which can be used to finance projects for small sub-contractors. Dialogue between the GORTT, energy companies, trade unions, and other relevant stakeholders is required to help resolve operations challenges limiting supply capacity. This is a critical factor as bpT'T has cited "competitiveness challenges" as the main reason why the Angelin gas platform will not be built in T\&T. Such a project, which would cost approximately US $\$ 2$ billion, could have definitely boosted T\&T's energy sector in 2017
(ECA 2017).

Local content can increase the amount of value added captured domestically in T\&T. Indeed, it can generate more employment for nationals of T\&T. However, the policy framework could be enhanced to encourage the production of more domestic inputs, develop the competencies of human capital, and encourage entrepreneurship of nationals.

\section{REFERENCES:}

BpTT (British Petroleum Trinidad and Tobago). 2016. "What we do." Accessed January 5, 2015.

http://www.bp.com/en_tt/trinidadand-tobago/about-bp-in-trinidad-andtobago/BPin'T'Thtml

ECA (Employers Consultative Association). 2017. "ECA Statement on Construction of bpTT's Angelin platform." Accessed May 14, 2017. http://www.ecatt.org/index.php/ media-centre/articles/426-ecastatement-on-construction-of-bptt-sangelin-platform

STOW. 2015. "Safe to Work (STOW)." Accessed December 9, 2015.

http:/ / www.stowtt.info/index. php?categoryid $=13$

Tordo, Silvana, Michael Warner, Osmel Manzano, and Yahya Anouti. 2013. Local Content Policies in the Oil and Gas Sector. World Bank Publications.

Triniview. 2004. "The Cannonball Project: Trinidad Raises First Offshore Gas Rig." November 22, 2004. Accessed November 3, 2015.

http://www.triniview.com/business/ cannonball.html

World Bank. 2017. "World Bank Commodities Price Forecast." Accessed May14,2017.http://pubdocs.worldbank. org/en/926111485188873241/CMOJanuary-2017-Forecasts.pdf. 


\section{IMPROVING EXPORT PERFORMANCE AND PROMOTING INDUSTRIALIZATION IN CARIBBEAN: THE CURIOUS CASE OF GOODS PRODUCING ECONOMIES}

In speaking to the issue of value chain participation, the analyses undertaken by ECLAC suggests that the bilateral intra-industry trade relations are either low or non-existent. As part of crafting the region's economic diversification strategy and broad export-development policy, it is necessary to conduct a more detailed analysis of value chains, focusing on industries with the most potential. These areas, together with the products and sectors identified earlier for Belize, Suriname and Trinidad and Tobago, must form an integral part of the thrust towards the development of clusters and value chains which can compete on the regional and international markets. In this regard, it is imperative that emerging industries where regional economies can contribute to the innovation and technological inputs, such as the creative industries, green industries, health and education (off-shore) as well as the ICT sectors and niche manufacturing, be given consideration.

The private sector should be central to this industrial restructuring and export diversification process, and therefore embedded within the framework of public policy intervention. It is important for regional policy makers to engage in continuous dialogue with exporters. A dialogue which opens up real possibilities for fashioning the most appropriate policy prescriptions geared towards remedying technological, informational and coordination externalities where they exist as well as addressing in a meaningful way the production and export expansion.
The objective is to create a policy framework for effectively fostering industrialization, strategy leading to a more diversified production structure, which increases economic growth, builds resilience and minimizes rent seeking behavior. Facilitating the entrepreneurial self-discovery process, which should not stray too far from the areas of comparative advantage of each country, is key in this regard. The truth is that the private sector has credible information on what are the true constraints to export diversification and sectors (and industries) which may be considered in a diversification trust. The issue here is not that of picking winners, but avoiding failures although this to some extent is part of the process of self-discovery.

\section{CONCLUSION:}

The successful integration of individual Caribbean economies into the multilateral trading system requires not only increased market access but also investment and policy frameworks geared towards inducing the requisite structural change.

Essential in this respect is undoubtedly the facilitation of increased privatepublic sector collaboration, as well as the strengthening of trade-related infrastructure; the identifying of new export sectors and the reorienting of the allocation of resources towards diversifying production and exports (i.e. new products and new markets). In other words, in order to create the desired delicate balance between integration into the global economy, generating and delivering welfare gains from increased trade to the small vulnerable economies of the Caribbean, the pivot must be moved decidedly closer towards formulating coherent private sector embedded industrial policies, which are export-centered and of which trade-related policies are an integral part.

\section{SOURCES:}

Amurgo - Pacheco, Alberto and Martha Denisse Pierola, 2008. Pattersn of Export Diversification in Developing Countries: intensive and extensive margins. The World Bank Policy Research Working Paper.

Hausmann, Ricardo and Dani Rodrik, 2002. Economic Development as Self Discovery. National Bureau of Economic Research, Working Paper 8952.

Lin, Justin and Ha-Joon Chang, 2009. Should Industrial policy in developing countries conform to comparative advantage or defy it? Development Policy Review, 2009, 27 (5)

McLean, Sheldon and RanjitSingh, 2017. Improving export trade performance in selected Caribbean countries: Trinidad and Tobago, Suriname and Belize. (Unpublished)

Rodrik, Dani, 2004. Industrial Policy for the Twenty-First Century. Faculty Research Working Papers Series, Harvard University. 


\section{RECENT AND UPCOMING MEETINGS}

APRIL

24 - 26 April 2017

Forum on Internet of Things (IOT): Smarter Living in the Caribbean - Port of Spain, Trinidad and Toabgo

27 - 28 April 2017

Digital Financial Services (DFS) Workshop - Port of Spain, Trinidad and Toabgo

\section{MAY}

18 May 2017

Workshop to accelerate SDG implementation in the Caribbean - Port of Spain, Trinidad and Toabgo

19 May 2017

Eighteenth meeting of the Monitoring Committee of the Caribbean Development and Cooperation Committee

- Port of Spain, Trinidad and Tobago

\section{List of Recent ECLAC Documents and Publications}

Listed by Symbol Number, Date and Title

\section{No. LC/CAR/L.508 January 2017}

Report of the Caribbean seminar on women's empowerment and migration in the Caribbean

No. LC/CAR/L.509 January 2017

Report of the technical meeting to examine the economic autonomy of women in the Caribbean

\section{No. LC/TS.2017/33}

March 2017

Assessing opportunities for enhanced integration of the associate members of the Economic Commission for Latin America and the Caribbean

No. LC/CAR/TS.2017/3

May 2017

Preliminary overview of the economies of the Caribbean 2016-2017 


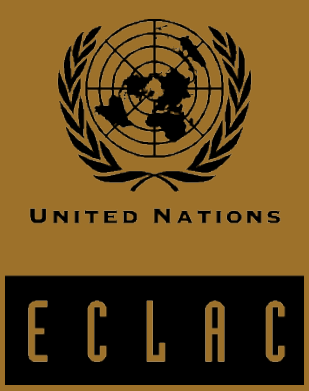

The Magazine of the Caribbean Development and Cooperation Committee ECLAC Subregional Headquarters for the Caribbean

PO Box 1113, Port of Spain, Trinidad and Tobago

Tel: 868-224-8000

E-mail: spou-pos@eclac.org

vrb.al/eclaccaribbean 